\title{
DEMOGRAFINIŲ VEIKSNIŲ İTAKA PACIENTŲ, SERGANČIŲ ÜMINIU KORONARINIU SINDROMU, SU SVEIKATA SUSIJUSIAI GYVENIMO KOKYBEI
}

\author{
Julijana Zoberniené ${ }^{1}$, Vida Mockiene $\dot{e}^{2}$ \\ ${ }^{1}$ Klaipèdos jürininku ligonine, ${ }^{2}$ Klaipédos universitetas
}

Raktažodžiai: demografiniai veiksniai, gyvenimo kokybè, išeminè širdies liga, pacientai, ūminis koronarinis sindromas.

\begin{abstract}
Santrauka
Viena iš svarbiausių širdies ir kraujagyslių ligų yra ūminis koronarinis sindromas (ŪKS), kuris sukelia pavojų gyvybei, todèl aktualu atkreipti dèmesị i pacientų su sveikata susijusią gyvenimo kokybę. Tyrimo tikslas - išanalizuoti demografinių veiksnių įtaką pacientų, sergančių ūminiu koronariniu sindromu, su sveikata susijusiai gyvenimo kokybei.Tyrimo metodika. Atliktas kiekybinis tyrimas. Duomenų rinkimui naudotas SF- 36 klausimynas. Taikytas statistinis duomenu paketas „SPSS 17 for Windows“. Tyrimo imtį sudarè 110 pacientų, sergančių ŪKS. Tyrimas atliktas vadovaujantis tyrimų etikos principais. Išanalizavus pacientų, sergančių ŪKS su sveikata susijusią gyvenimo kokybę priklausomai nuo lyties nustatytas reikšmingas $(p<0,05)$ veiklos apribojimas dèl fizinių, emociniu problemu - moterys kur kas ženkliau akcentavo fizines, emocines problemas nei vyrai. Nedirbantys bei turintys vidurini/spec. vidurini išsilavinimą žymiai prasčiau vertino bendrą sveikatą ir fizinį aktyvumą, savo emocinę būklę ir socialinę funkciją, veiklos apribojimą dẻl emocinių problemų. Išvada. Tiriant pacientų, sergančių ūminiu koronariniu sindromu, su sveikata susijusią gyvenimo kokybę paaiškejjo, jog priklausomai nuo lyties moterys reikšmingai blogiau vertino fizines problemas, labiau akcentavo skausmą, prasčiau vertino bendrą sveikatą ir emocines problemas.
\end{abstract}

\section{Ivadas}

Pasaulio sveikatos organizacijos (PSO) Europos sveikatos politikos dokumento „Sveikata visiems XXI amžiuje“ 8-asis tikslas skelbia - iki $2020 \mathrm{~m}$. visame regione iki mažiausio imanomo lygio turi būti sumažintas sergamumas, negalia ir priešlaikinès mirtys dèl pagrindinių lètinių ligų, o konkrečiai - mažiausiai 40 proc. turi būti sumažintas jaunesnių negu 65 metų amžiaus žmonių mirtingumas dẻ širdies ir kraujagyslių ligų [1]. Buvo apskaičiuota, kad iki 2050 m. žmonių Europoje per 50 metų amžiaus skaičius išaugs 35 proc., o vyresnių nei 85 metų amžiaus bus trigubai. Be to, prognozuojama, kad vienas iš trijų senyvo amžiaus žmonių greičiausiai kentès nuo lètinès ligos ar negalios, įskaitant širdies ir kraujagyslių ligas, kurios riboja jų savarankiškumą [2].

Lietuvos gyventojų sergamumas ir mirtingumas nuo širdies ir kraujagyslių ligų užima pirmą vietą, o mirštamumo ir mirtingumo pokyčiai susiję su mūsų šalies ekonominiu išsivystymu, asmens sveikatos priežiūros teikiamų paslaugų kokybe ir prieinamumu [3]. Lietuvoje, kaip ir visoje Europoje, širdies ir kraujagyslių ligos tebèra pagrindinė mirties priežastis. Lietuvoje miršta beveik dvigubai daugiau gyventojų, nei vidutiniškai Europos sajungos šalyse senbuvèse. Šis rodiklis yra ypač didelis vyresnių nei $64 \mathrm{~m}$. asmenų amžiaus grupeje, kurioje net 66 proc. mirties atvejų priežastis yra širdies ir kraujagyslių ligos. Šios ligos yra tipiné senstančios visuomenès problema [4].

Viena iš svarbiausių širdies ir kraujagysliu ligų yra ūminis koronarinis sindromas (toliau ÜKS), kuris sukelia pavojų gyvybei. Šis sindromas gali pereiti nuo nestabilios krūtinès anginos i ūmini miokardo infarktą (ŪMI) ir negrị̌tamos nekrozès miokarde. Lietuvoje P. Šerpyčio ir kt. [4], E. Rinkūnienès ir kt. [1], Ž. Petrulionienès ir kt. atlikti tyrimai [5] rodo mažejjantị letalumą nuo ŪMI atitinkamai ir vyrų, ir moterų, o hospitalizuotų pacientų, sergančių ŪMI, vis daugeja.

Širdies ligos sutrikdo fizinio krūvio toleranciją, socialinį aktyvumą, ekonominį nepriklausomumą. Gyvenimo kokybę sunkina tai, kad pacientai priversti ilgą laiką reguliariai vartoti vaistus. Dažnai sutrinka tokių ligonių dèmesys, budrumas, atmintis, orientacija, mąstymas, suvokimas. Gyvenimo kokybès vertinimas tapo toks pat svarbus kaip ir iprastai atliekami instrumentiniai tyrimo metodai. Gyvenimo kokybès samprata leidžia ịvertinti, kiek pacientas jaučiasi ligotas [6]. Tiriant su sveikata susijusią gyvenimo kokybę, siekiama 
dvejopos informacijos: apie paciento funkcinę būklę ir jo paties vertinimo, kaip sveikata daro įtaką jo gyvenimo kokybei [7].

Didejantis sergamumas širdies ir kraujagyslių ligomis skatina ir didesnį demesi jomis sergantiems pacientams. Su sveikata susijusios gyvenimo kokybės tyrimas, kuri atlieka patys pacientai, yra labai aktualus. Išsamūs pacientų, sergančių ūminiu koronariniu sindromu, su sveikata susiję tyrimai paremti pačių pacientų supratimu apie jų sveikatą, savęs vertinimu bei pastangomis suprasti ligą.

Tyrimo tikslas - išanalizuoti demografinių veiksnių įtaką pacientų, sergančių ūminiu koronariniu sindromu, su sveikata susijusiai gyvenimo kokybei

\section{Tyrimo medžiaga ir metodas}

Tyrimas atliktas $2016 \mathrm{~m}$. lapkričio/vasario mèn. Klaipèdos ligoninèje, teikiančioje antrinio lygio paslaugas. Tiriamajji kontingentą sudare 110 pacientų, sergančių ūminiu koronariniu sindromu, po atlikto koronarografijos tyrimo ir/ar atliktos perkutaninès koronarinès intervencijos - 64,5 proc. vyrų ir 35,5 proc. moterų. Pagal amžių daugiausia (40,9 proc.) tiriamujų buvo vyresnių nei 60 metų, 5160 metų buvo 38,2 proc. ir 20,9 proc. - iki 50 metų. 54,5 proc. tiriamųjų turèjo vidurinị/specialųji vidurini išsilavinimą, 26,4 proc. - aukštesnijị /koleginị ir 19,17 proc. - aukštajị. Tiriamujų iš miestų buvo dauguma $(65,5$ proc.), iš kaimo/gyvenviečių - 34,5 proc. Dauguma (61,8 proc.) tiriamujjų buvo dirbantys asmenys. Iš nedirbančiųu $(38,2$ proc.) dauguma (25,5 proc.) buvo pensinio amžiaus asmenys, kitą dalị sudaré neigalūs ( 8,2 proc.) ir bedarbiai (4,5 proc.).

Tyrimui atlikti buvo pasirinkta anketinè apklausa. Instrumentas sudarytas iš dviejų dalių: klausimai apie demografinius duomenis (amžius, lytis, išsilavinimas, socialinè padètis, gyvenamoji vieta), klausimas apie lètines ligas ir SF - 36 klausimynas, trumpa sveikatos apklausos forma (angl. Short Form 36 Medical Outcomes Study questionnaire). Atsakymai i klausimus buvo vertinami balais. Kiekviena skale naudojant skaičiavimo algoritmą vertinama nuo 0 iki 100. Kuo didesnis balų skaičius, tuo geresnè gyvenimo kokybė (100 balų rodo geriausią įvertinimą). Darbe naudojamo SF-36 klausimyno vidinis patikimumas buvo pakankamas Kronbacho (Cronbach) alfa 0,726.

Tyrimo rezultatu analizei buvo naudojamas statistinis paketas „SPSS 17 for Windows“. Tikrintas kintamųu pasiskirstymas pagal normaluji dèsnị, taikant KolmogorovoSmirnovo (Kolmagorov-Smirnov) testą. Esant normaliam pasiskirstymui duomenys pateikti vidurkis \pm standartinis nuokrypis, nesant - vidurkis (mediana). Požymių, turinčių normalųji pasiskirstymą, palyginimui tarp dviejų nepriklausomų grupių naudotas neporinis Stjudento (Student) (t) kriterijus, o neturintiems normalaus pasiskirstymo - neparametrinis Mano Vitney (Mann-Whitney) (U) kriterijus. Požymių, turinčių normalüj pasiskirstymą, palyginimui tarp trijų nepriklausomų grupių naudotas One-Way ANOVA (F) metodas, su daugkartiniu Post-Hoc LSD kriterijumi, o neturintiems normalaus pasiskirstymo - neparametrinis Kruskalio-Volio (Kruskal-Vallis) $\left(\chi^{2}\right)$. Naudoti statistinių hipotezių reikšmingumo lygmenys: kai $\mathrm{p}<0,05\left(^{*}\right)$ - reikšmingas, kai $\mathrm{p}<0,01$ $(* *)$ labai reikšmingas, kai $\mathrm{p}<0,001(* * *)$ - itin reikšmingas ir $p>0,05$ - statistiškai nereikšmingas.

\section{Tyrimo rezultatai}

Pasiteiravus tiriamujų, kaip jie vertina savo sveikatą, nustatyta, kad pusé (50 proc.) tiriamujų ją vertino blogai, o 22,7 proc. - net labai blogai ir tik 27,3 proc. - savo sveikatą vertino gerai. Analizuojant tiriamujų nuomonę apie jų sveikatą, jų vertinimui buvo pateikti tokie teiginiai: „Man atrodo, kad aš labiau linkęs sirgti negu kiti žmonès“, „Ǎ̌ esu toks sveikas kaip ir kiti, ka aš pažįstu“, „Aš manau, kad mano sveikata blogés“ ir „Mano sveikata puiki“ pasirenkant atsakymo variantą nuo „Tiksliai teisingas“ iki „Tiksliai klaidingas“. Tyrimo rezultatai parodè, kad maždaug pusé tiriamujų nemanè, kad jų sveikata yra puiki (48,2 proc.), 37,2 proc. - mané, kad jų sveikata dar labiau blogès, 38,2 proc. - buvo linkę manyti, kad jie nèra tokie sveiki, kaip kiti, ką jie pažista ir 22,8 proc. - linkę labiau sirgti negu kiti žmonès. Nebuvo įsitikinę šiais aspektais nuo $36,4-51,8$ proc.

Pasiteiravus tiriamujų , kokio intensyvumo būdavo kūno skausmai per pastarąsias 4 savaites, nustatyta, kad 40,9 proc. jų jaute vidutinio intensyvumo skausmus, stiprius $-12,7$ proc., labai stiprius $-4,5$ proc., silpnus $-16,4$ proc., labai silpnus $-18,2$ proc. ir visai skausmų nejautė 7,3 proc. tiriamujų. Tyrimas parodè, kad didžiajai daliai tiriamujų $(90$ proc.) skausmas turejo neigiamos įtakos jų darbui - 35,4 proc. tiriamujų skausmas trukdè, bet labai nedaug, 28,2 proc. - vidutiniškai trukdè, 19,1 proc. - gana žymiai trukdè ir 7,3 proc. - labai trukdè. Skausmas neturèjo įtakos darbui 10 proc. tiriamujų.

Analizuojant tiriamujų su fizine sveikata susijusią gyvenimo kokybę priklausomai nuo lyties nustatytas reikšmingas $(p<0,05)$ veiklos apribojimo dèl fizinių problemų skirtumas - moterys žymiai prasčiau vertino veiklos apribojimą dèl fizinių problemų nei vyrai (moteru grupejje 29,49(25,0) balu ir vyru grupejje 45,77(50,0) balų: $U=1038,50 \mathrm{p}=0,026)$. Kiti gyvenimo kokybès, susijusios su fizine sveikata, rodikliai reikšmingai nesiskyrė tarp vyrų ir moterų, tačiau stebèta tendencija, kad moterys šiek tiek prasčiau vertino ją nei vyrai - moterys buvo nežymiai mažiau fiziškai aktyvios (moteru grupejje $57,56 \pm 20,90$ balų ir vyrų grupeje $61,69 \pm 23,99$ balų: 
$\mathrm{t}=0,939 \mathrm{p}=0,350$ ), labiau akcentavo skausmą (moteru grupèje $47,33 \pm 22,42$ balų ir vyru grupejje $51,02 \pm 23,88$ balų: $t=0,808$ $\mathrm{p}=0,422$ ) ir prasčiau vertino bendrą sveikatą (moterų grupeje $40,41 \pm 17,22$ balų ir vyru grupeje $42,80 \pm 18,30$ balų: $t=0,682$ $\mathrm{p}=0,497$ ) nei vyrai (1 pav.).

Analizuojant tiriamujų su psichine sveikata susijusią gyvenimo kokybę priklausomai nuo lyties nustatytas reikšmingas $(p<0,05)$ veiklos apribojimo dèl emociniu problemų vertinimų skirtumas - moterys žymiai labiau akcentavo veiklos apribojimą dèl emocinių problemų (moterų grupéje $39,32(33,33)$ balų ir vyru grupejje $60,09(66,67)$ balų: $\mathrm{U}=971,0 \mathrm{p}=0,007)$. Kiti gyvenimo kokybès, susijusios su psichine sveikata, vertinimai tarp vyrų ir moterų reikšmingai nesiskyrè (2 pav.).

Vertinant su fizine sveikata susijusią gyvenimo ko-



1 pav. Sergančiujų ŪKS su fizine sveikata susijusios gyvenimo kokybės rodiklių skirtumai priklausomai nuo lyties (Taikytas Mano Vitney kriterijus)

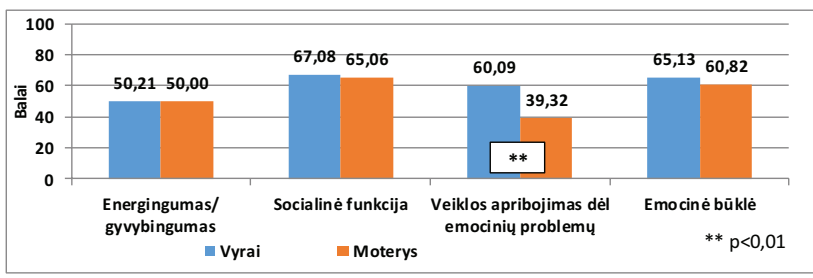

2 pav. Sergančiųjų ŪKS su psichine sveikata susijusios gyvenimo kokybės rodiklių skirtumai priklausomai nuo lyties (Taikytas Mano Vitney kriterijus)

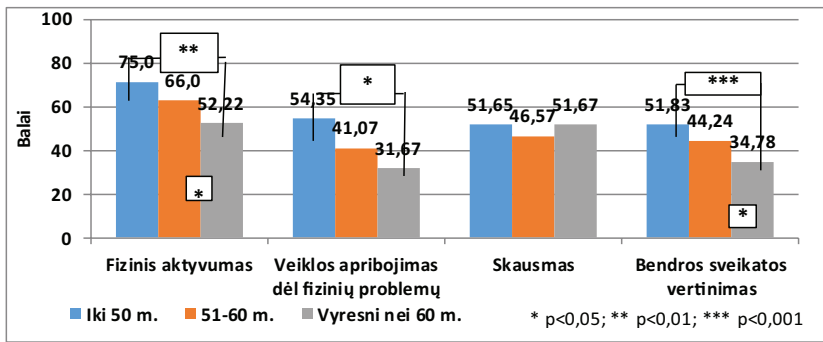

3 pav. Sergančiųjų ŪKS su fizine sveikata susijusios gyvenimo kokybès rodiklių skirtumai priklausomai nuo amžiaus (Taikytas Mano Vitney kriterijus) kybę priklausomai nuo amžiaus nustatyta, kad vyresni nei 60 metų tiriamieji reikšmingai prasčiau vertino savo bendrą sveikatą (vyresnių nei $60 \mathrm{~m} .34,78 \pm 19,32$ balų, 51-60 metų 44,24 $\pm 12,91$ balų ir iki 50 metų $51,83 \pm 17,59$ balų: $\mathrm{F}=8,502 \mathrm{p}<0,001$ ) ir fizini aktyvumą (vyresnių nei $60 \mathrm{~m}$. $52,22 \pm 23,93$ balų, 51-60 metu $62,74 \pm 20,40$ balų ir iki 50 metų 71,30 $\pm 21,49$ balų: $F=6,22 \mathrm{p}=0,003$ ) nei $51-60$ metų ir ypač nei iki 50 metų. Be to, tyrimas parodè, kad vyresnių nei 60 metų tiriamujų veikla dèl fizinių problemų buvo reikšmingai $(\mathrm{p}<0,05)$ labiau apribota (vyresnių nei $60 \mathrm{~m} .31,67(25,0)$ balų ir iki 50 metų $54,35(50,0)$ balų: $U=341,50 \mathrm{p}=0,018)$ nei iki 50 metų asmenų. Tarp skausmo vertinimų priklausomai nuo amžiaus reikšmingų skirtumų nenustatėme (3 pav.).

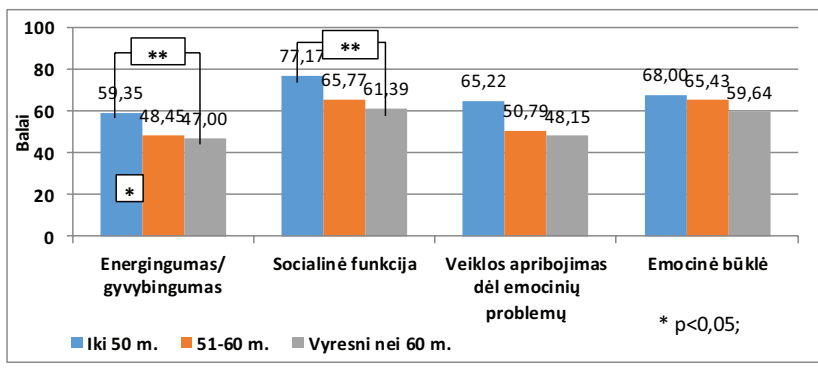

4 pav. Sergančiųu ūminiu koronariniu sindromu su psichine sveikata susijusios gyvenimo kokybės priklausomai nuo amžiaus (Taikytas One-Way ANOVA metodas)

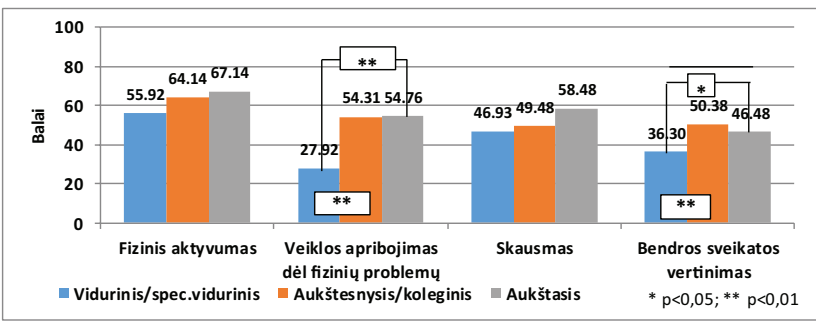

5 pav. Sergančiųjų ŪKS su fizine sveikata susijusios gyvenimo kokybės rodiklių skirtumai priklausomai nuo išsilavinimo (Taikytas One-Way ANOVA metodas)

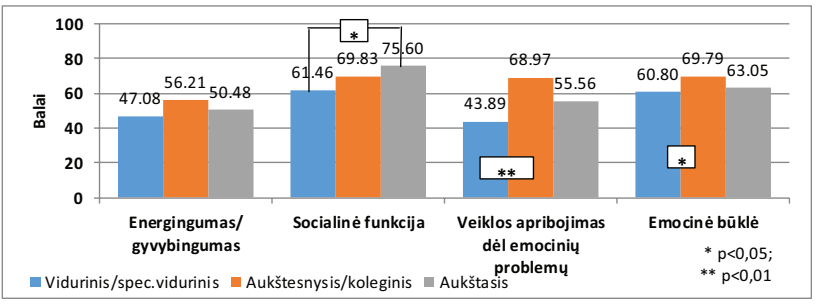

6 pav. Sergančiųų ŪKS su psichine sveikata susijusios gyvenimo kokybès rodiklių skirtumai priklausomai nuo išsilavinimo (Taikytas One-Way ANOVA metodas) 
Vertinant su psichine sveikata susijusią gyvenimo kokybę priklausomai nuo amžiaus nustatyta, kad vyresni nei 60 metų tiriamieji reikšmingai prasčiau vertino savo socialinę funkciją (vyresnių nei $60 \mathrm{~m} .61,39 \pm 25,95$ balų, 51-60 metų $65,77 \pm 20,29$ balų ir iki 50 metų $77,17 \pm 19,46$ balų: $\mathrm{F}=3,722 \mathrm{p}=0,027)$ nei jaunesni tiriamieji ir ypač nei iki 50 metų. Energingumą/gyvybingumą reikšmingai geriau vertino patys jauniausi tiriamieji būtent iki 50 metu nei 51-60 metų ir ypač nei 61 metų ir vyresni tiriamieji (iki 50 metu $59,35 \pm 20,19$ balų, 51-60 metų 48,45 $\pm 14,63$ balų ir vyresnių nei $60 \mathrm{~m} .47,00 \pm 17,40$ balų: $F=4,329 \mathrm{p}=0,016)$. Reikšmingu skirtumų vertinant veiklos apribojimą dèl emocinių problemų ir emocinę būklę priklausomai nuo amžiaus nebuvo nenustatyta (4 pav.).

Vertinant su fizine sveikata susijusią gyvenimo kokybę priklausomai nuo išsilavinimo nustatyta, kad su viduriniu/ spec. viduriniu išsilavinimu tiriamieji reikšmingai prasčiau vertino savo bendrą sveikatą (su viduriniu/spec. viduriniu $36,30 \pm 16,23$ balų, su aukštesniuoju/koleginiu 50,38 $\pm 14,65$

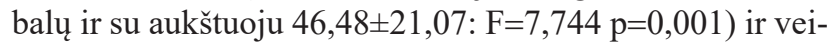
klos apribojimą dèl fizinių problemų (su viduriniu/spec. viduriniu 27,92(25,0) balų, su aukštesniuoju/koleginiu $54,31(50,0)$ balų ir su aukštuoju 54,76(50,0) balų: $\chi^{2}=13,908$ $\mathrm{p}=0,001)$ nei tiriamieji su aukštesniuoju/koleginiu ir aukštuoju išsilavinimu. Tarp fizinio aktyvumo ir skausmo vertinimų priklausomai nuo išsilavinimo reikšmingų skirtumų nenustateme (5 pav.).

Vertinant su psichine sveikata susijusią gyvenimo kokybę priklausomai nuo išsilavinimo nustatyta, kad su viduriniu/ spec. viduriniu išsilavinimu tiriamieji reikšmingai prasčiau vertino savo veiklos apribojimą dèl emocinių problemų (su viduriniu/spec. viduriniu 43,89 $(33,33$ ) balų, su aukštesniuoju $68,97(66,67)$ balų ir su aukštuoju 55,56(66,67) balų: $\chi 2=8,212 \mathrm{p}=0,016$ ) ir emocinę būklę (su viduriniu/ spec. viduriniu $60,80 \pm 16,97$ balų, su aukštesniuoju/koleginiu $69,79 \pm 14,29$ balų ir su aukštuoju $63,05 \pm 14,91$ balų: $\mathrm{F}=3,132 \mathrm{p}=0,048$ ) nei tiriamieji su aukštesniuoju/koleginiu išsilavinimu. Tiriamieji su viduriniu/spec. viduriniu išsilavi-

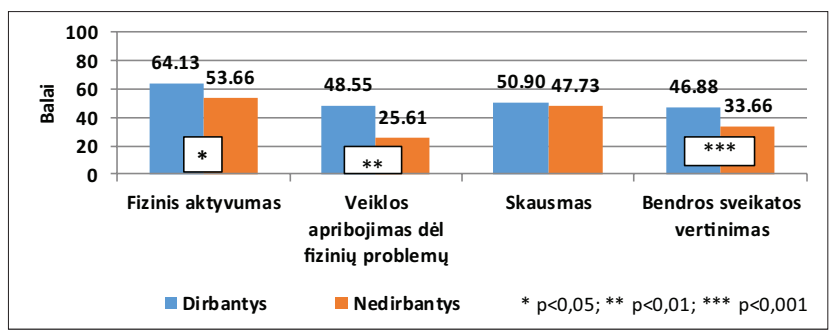

7 pav. Sergančiųjų ŪKS su fizine sveikata susijusios gyvenimo kokybės rodiklių skirtumai priklausomai nuo darbinès padèties (Taikytas Mano Vitney kriterijus) nimu reikšmingai prasčiau vertino savo socialinę funkciją (su viduriniu/spec. viduriniu $61,46 \pm 24,39$ balų, su aukštesniuoju/ koleginiu $69,83 \pm 19,34$ balų ir su aukštuoju $75,60 \pm 21,82$ balų: $F=3,478 \mathrm{p}=0,034)$ nei su aukštuoju išsilavinimu. Tarp energingumo/gyvybingumo vertinimu priklausomai nuo išsilavinimo reikšmingų skirtumų nenustatyta (6 pav.).

Analizuojant tiriamujų su fizine sveikata susijusią gyvenimo kokybę priklausomai nuo gyvenamosios vietos reikšmingu $(p<0,05)$ skirtumų nenustatyta. Su psichine sveikata susijusi gyvenimo kokybė tarp tiriamujų grupių priklausomai nuo gyvenamosios vietos taip pat reikšmingai nesiskyrè.

Vertinant su fizine sveikata susijusią gyvenimo kokybę priklausomai nuo darbinès padèties nustatyta, kad nedirbantys reikšmingai prasčiau vertino savo bendrą sveikatą

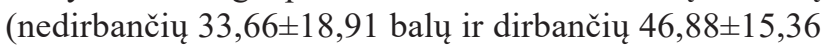
balų: $\mathrm{t}=4,001 \mathrm{p}<0,001$ ) ir fizini aktyvumą (nedirbančių $53,66 \pm 24,32$ balų ir dirbančių $64,13 \pm 21,30$ balų: $t=2,285$ $\mathrm{p}=0,025)$, labiau akcentavo veiklos apribojimą dèl fizinių problemų (nedirbančių 25,61(0) balų ir dirbančių 48,55(50,0) balų: $U=888,50 \mathrm{p}=0,001)$ nei dirbantys. Gyvenimo kokybę dèl skausmo nedirbantys ir dirbantys vertino panašiai (7 pav.).

Vertinant su psichine sveikata susijusią gyvenimo kokybę priklausomai nuo darbinès padèties nustatyta, kad nedirbantys reikšmingai $(p<0,05)$ prasčiau vertino savo socialinę funkciją (nedirbančių 58,23 $\pm 24,94$ balų ir dirbančių $71,20 \pm 21,82$ balų: $t=2,799 \mathrm{p}=0,007$ ) ir emocinę būklę (nedirbančių $56,88 \pm 17,12$ balų ir dirbančių $67,59 \pm 14,38$ balų: $\mathrm{t}=3,364 \mathrm{p}=0,001)$, labiau akcentavo veiklos apribojimą dèl emocinių problemų (nedirbančių 38,21 $(33,33)$ balų ir dirbančių $61,35(66,67)$ balų: $U=946,50 p=0,003)$ nei dirbantys. Energingumo/gyvybingumo vertinimai priklausomai nuo darbinès padèties reikšmingai nesiskyrè (8 pav.).

45,5 proc. tiriamujų sirgo dar ir kita lètine liga. Tyrimas parodè, kad moterys reikšmingai $\left(\chi^{2} 6,304 \mathrm{p}=0,012\right)$ dažniau sirgo lètinèmis ligomis nei vyrai (1 lentelè).

Analizuojant tiriamujų su fizine sveikata susijusią gyvenimo kokybę priklausomai nuo kitų lètinių ligų buvimo reikšmingų $(\mathrm{p}<0,05)$ skirtumų. Su psichine sveikata susijusi

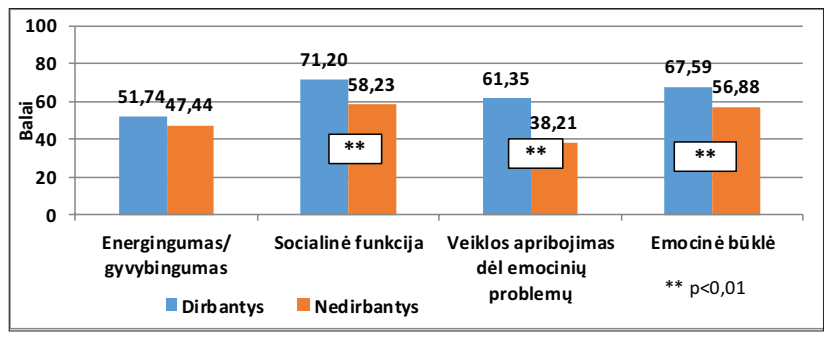

8 pav. Sergančiųjų ŪKS su psichine sveikata susijusios gyvenimo kokybès rodiklių skirtumai priklausomai nuo darbinès padèties (Taikytas Mano Vitney kriterijus) 
1 lentelè. Sergančiųų ŪKS vyrų ir moterų pasiskirstymas priklausomai nuo lètinių ligų susirgimų

\begin{tabular}{|l|c|c|c|c|}
\hline $\begin{array}{l}\text { Ar sergate ko- } \\
\text { kiomis nors lèti- } \\
\text { nėmis ligomis? }\end{array}$ & Vyrai & Moterys & $\chi^{2}$ & p \\
\hline $\begin{array}{l}\text { Taip } \\
\mathrm{Ne}\end{array}$ & $26(36,6$ proc.) & $24(61,5$ proc. $)$ & & \\
\hline
\end{tabular}

gyvenimo kokybė tarp tiriamųų grupių priklausomai nuo kitų lètinių ligų buvimo taip pat reikšmingai nesiskyrè

Analizuojant gyvenimo kokybės, susijusios su sveikata, vertinimus priklausomai nuo lyties ir lètinių ligų buvimo nustatyta, kad moterų sergančių lètinėmis ligomis, reikšmingai buvo apribota veikla dèl fizinių (atitinkamai 21,88(0) balų ir $51,92(50,0)$ balų: $\mathrm{U}=150,0 \mathrm{p}=0,001)$ ir emociniu (atitinkamai $38,89(33,33)$ balu ir $70,51(66,67)$ balų: $U=162,0 \mathrm{p}=0,003)$ problemų nei vyrų, sergančių lètinèmis ligomis. Tuo tarpu vyrai, sergantys lètinèmis ligomis, reikšmingai geriau vertino savo energingumą/gyvybingumą nei nesergantys lètinèmis ligomis (atitinkamai $56,35 \pm 17,92$ balų ir $46,67 \pm 19,51$ balų: $\mathrm{t}=2,12 \mathrm{p}=0,038)$.

\section{Rezultatų aptarimas}

Analizuojant sergančiųų ūminiu koronariniu sindromu su sveikata susijusią gyvenimo kokybę ir ją lemiančius veiksnius nustatyta, kad vyrai ir moterys skirtingai vertino su sveikata susijusią gyvenimo kokybę. Šiame darbe buvo tiriama, kokias su sveikata susijusias gyvenimo kokybės sritis vyrai ir moterys, sergantys ŪKS, vertina skirtingai. Analizuojant tiriamujų su fizine sveikata susijusią gyvenimo kokybę priklausomai nuo lyties reikšmingų $(p<0,05)$ skirtumų nustatyta: moterys žymiai prasčiau vertino ją nei vyrai. Jos labiau akcentavo skausmą ir prasčiau vertino bendrą sveikatą, moterų fizinè veikla buvo žymiai labiau apribota dèl emocinių problemų nei vyrų $(\mathrm{p}<0,05)$. D. R Thompson ir kt. [8] savo tyrime nustate, kad sergančiosios širdies ir kraujagyslių ligomis moterys prasčiau vertino bendrą gyvenimo kokybę ir fizinę gyvenimo kokybès sritį. Tai pastebejjo atliktuose tyrimuose ir J. Laurinskaitė ir kt. [9], M. Staniūtė ir kt. [10], rezultatai sutapo.

Vertinant su fizine sveikata susijusią gyvenimo kokybę priklausomai nuo amžiaus nustatyta, kad vyresni nei 60 metų tiriamieji reikšmingai $(p<0,001)$ prasčiau vertino savo bendrą sveikatą nei 51-60 metų ir ypač nei iki 50 metų ( $p=0,011$, $\mathrm{p}=0,005)$. A Wikman [11] ir E. S. Leigh [12] tyrimų duomenimis, tiriamieji, vyresni nei 60 metų, bendrą sveikatą taip pat vertino prasčiau. Be to, tyrimai parodè, kad vyresnių nei 60 metų tiriamujų buvo reikšmingai $(p<0,05)$ mažesnis fizinis aktyvumas ir jų veikla dèl fizinių problemų buvo reikšmingai $(p<0,05)$ labiau apribota nei iki 50 metų asmenų.

Analizuojant su fizine ir psichine sveikata susijusią gyvenimo kokybę priklausomai nuo išsilavinimo nustatyta, kad su viduriniu/spec. viduriniu išsilavinimu tiriamieji reikšmingai prasčiau vertino savo bendrą sveikatą ir veiklos apribojimą dèl fizinių problemų, fizini aktyvumą nei tiriamujų su aukštesniuoju/koleginiu ar aukštuoju išsilavinimu. Tiriamieji su viduriniu/spec. viduriniu išsilavinimu reikšmingai $(p<0,05)$ prasčiau vertino savo emocinę būklę ir veiklos apribojimą dèl emocinių problemų, savo socialinę funkciją nei su aukštuoju išsilavinimu.

Vertinant su fizine ir psichine sveikata susijusią gyvenimo kokybę priklausomai nuo darbinès padèties nustatyta, kad nedirbantys reikšmingai $(\mathrm{p}<0,001)$ prasčiau vertino savo bendrą sveikatą ir fizinį aktyvumą, labiau akcentavo veiklos apribojimą dèl fizinių problemų $(\mathrm{p}=0,001)$, nedirbantys taip pat reikšmingai $(\mathrm{p}<0,05)$ prasčiau vertino savo socialinę funkciją ir emocinę būklę, labiau akcentavo veiklos apribojimą dèl emocinių problemų nei dirbantys. Vertinant tiriamujų su fizine sveikata ir psichine sveikata susijusią gyvenimo kokybę priklausomai nuo gyvenamosios vietos reikšmingų skirtumų nenustatyta.

Analizuojant gyvenimo kokybės, susijusios su sveikata, vertinimus priklausomai nuo lyties ir lètinių ligų buvimo nustatyta, kad moterys reikšmingai ( $p<0,01)$ dažniau sirgo lètinèmis ligomis nei vyrai. Lètinès ligos moterims suteikè daugiau emocinių problemų, ribojo fizinę veiklą. Dviejų metu atliktame tyrime M. Tisminetzky ir kt. [13] Jungtinèse Amerikos Valstijose nustate, jog moterų taip pat buvo žymiai daugiau sergančių lètinėmis ligomis, kurios ribojo jų fizinę veiklą ir jos turejjo daugiau emocinių problemų.

\section{Išvados}

Tiriant pacientų, sergančių ūminiu koronariniu sindromu, su fizine ir psichine sveikata susijusios gyvenimo kokybès priklausomai nuo lyties - moterys reikšmingai prasčiau vertino fizines problemas, labiau akcentavo blogesnę bendrą sveikatą, skausmą ir reikšmingai prasčiau vertino emocines problemas.

Vertinant pagal amžiaus grupes - vyresniems nei 60 metų amžiaus tiriamiesiems buvo žymiai apribotas fizinis aktyvumas ir socialinè veikla, energingumas.

Nedirbantys bei turintys vidurinị/spec. vidurinị išsilavinimą reikšmingai prasčiau vertino bendrą sveikatą ir fizinị aktyvumą, savo emocinę būklę ir socialinę funkciją, veiklos apribojimą dèl emocinių problemų.

Tyrime tarp skausmo vertinimų nepriklausomai nei nuo amžiaus, išsilavinimo, darbingumo ar gyvenamos vietos reikšmingų skirtumų nenustatyta. 


\section{Literatūra}

1. Rinkūnienė E., Petrulionienė Ž., Zdanevičiūtė I., Dženkevičiūtė V. Mirtingumo nuo širdies ir kraujagyslių ligų tendencijos Lietuvoje ir Europos Sajungos šalyse. Medicinos teorija ir praktika, 2013; 2(19):130-136.

2. Jaarsma T, Deaton C, Fitzsimmons D. et al. Research in cardiovascular care: a position statement of the council on cardiovascular nursing and allied professionals of the European Society of Cardiology. European Journal of Cardiovascular Nurs 2014; 13(1):9-21. https://doi.org/10.1177/1474515113509761

3. Macas A., Ragaišis V., Butkevičiūtė M. Hemodinamikos rodiklių prognozinè verte, esant ūminio širdies nepakankamumo sindromui. Sveikatos mokslai, 2010; 3(69):54. ISSN 1392-2696.

4. Šerpytis P., Milčiute A., Karvelytė N ir kt. Atsparumo klopidogreliui ryšys su ūmia stento tromboze ir ūmia in-stent restenoze. Sveikatos mokslai, 2012; (22):91-95.

5. Petrulionienė Ž., Šerpytis P., Jančauskaitè D. ir kt. Moterų miokardo infarkto klinikinès simptomatikos ir baigčių ypatumai. Sveikatos mokslai, 2015;1(25):44-49. https://doi.org/10.5200/sm-hs.2015.007

6. Kubilius R., Česnavičiūtė I., Pereckaitè L., Rudys A. Pacientų, sergančių lètiniu sistoliniu širdies nepakankamumu, vaistų vartojimo problemos ir jų įtaka gyvenimo kokybei. Sveikatos mokslai, 2016; 26(2):41-46.

http://doi.org/10.5200/sm-hs.2016.024

7. Gedmintaitė L., Petruševičienė D., Lendraitienė E. ir kt. Asmenu gyvenimo kokybės ir savarankiškumo vertinimas ergoterapijoje, patyrus galvos smegenų insultą. Neurologijos seminarai, 2013; 17(57):198-202.

8. Thompson DR, Chair SY, Chan SW. et al. Motivational interviewing: a useful approach to improving cardiovascular health? Journal of Clinical Nursing 2011; 20(9-10):1236-1244. https://doi.org/10.1111/j.1365-2702.2010.03558.x

9. Laurinskaitė J., Šostakienė N., Darginavičienė R. Sveikatos rizikos veiksnių analizė ir valdymas sergant kardiologinėmis ligomis. Visuomenès sveikata, 2013; 1:121-128.

10. Staniūtè M., Brožaitienė J., Bunevičius R. Psichoemocinių veiksnių sąsajos su išemine širdies liga sergančių asmenų gyvenimo kokybė. Visuomenès sveikata, 2013; 1:129-134.

11. Wikman A, Molloy GJ, Randall G. et al. Cognitive predictors of posttraumatic stress symptoms six months following acute coronary syndrome. Psychology \& Health 2011; 26(8):974-988. https://doi.org/10.1080/08870446.2010.512663
12. Leigh ES, Wikman A, Molloy GJ. et al. The psychosocial predictors of long-term distress in partners of patients with acute coronary syndrome. Psychology \& Health 2014; 29(7):737-752. https://doi.org/10.1080/08870446.2014.882921

13. Tisminetzky M, Gurwitz J, McManus DD. et al. Multiple chronic conditions and psychosocial limitations in patients hospitalized with an acute coronary syndrome. The American Journal of Medicine 2016; 129(6):608 - 614 .

https://doi.org/10.1016/j.amjmed.2015.11.029

\section{THE IMPACT OF DEMOGRAPHIC FACTORS ON HEALTH - RELATED QUALITY OF LIFE OF PATIENTS WITH THE ACUTE CORONARY SYNDROME}

\section{J. Zobernienė, V. Mockienė}

Key words: acute coronary syndrome, demographic factors, health - related quality of life, patients, ischemic heart disease.

Summary

One of the main cardiovascular life - threatening diseases is an acute coronary syndrome (ACS). It is the reason to pay more attention to health-related quality of life of ACS patients. The aim of the research is to analyze the impact of demographic factors on health - related quality of life of patients with the acute coronary syndrome. Research methodology: The quantitative research was made. The SF-36 questionnaire was used for data collection. The statistical method of data processing was used. The sample of the research made $110 \mathrm{ACS}$ patients. The research was performed following the research ethics. Results of the research: The analysis of health - related life quality of ACS patients revealed, that depending on patients' sex, a significant activity limitation depending on physical or emotional problems was determined. Women elicited physical and emotional problems more often than men. Unemployed and people with secondary or special education assessed their physical health and activeness, emotional state, social functions and activity limitation because of emotional problems much more poorly.

Conclusion: The research revealed that more than a half of respondents, sick with ACS, assessed that women elicited pain and assessed general health worse emphasising emotional problems.

Correspondence to: j.zoberniene@gmail.com

Gauta 2017-09-08 